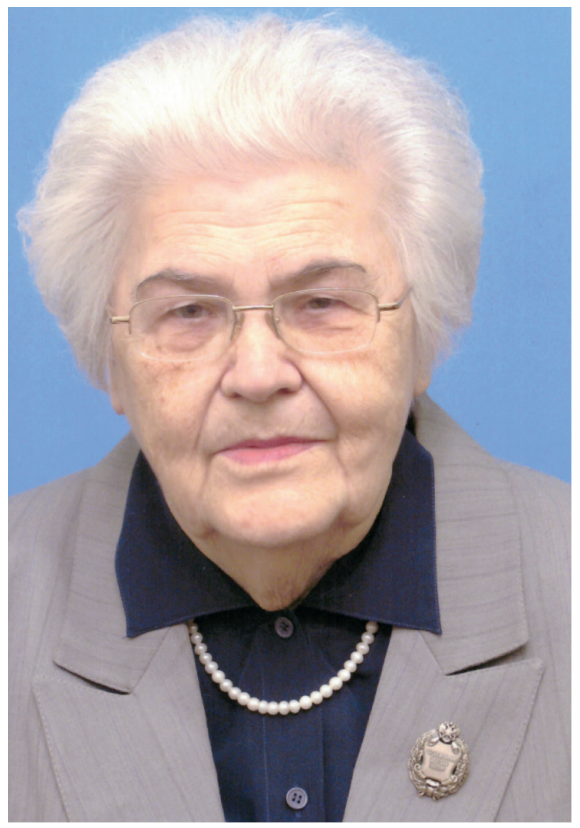

Вера Александровна Кочергина

(1924-2018)

\title{
In Memory of Vera Kochergina (1924-2018)
}

Двадцать четвертого февраля на девяносто четвертом году жизни скончалась Вера Александровна Кочергина - заслуженный деятель науки, заслуженный профессор Московского университета, доктор филологических наук.

Эти высокие звания, степени и должности, вехи многолетней научной и педагогической деятельности Веры Александровны, лишь внешне отражают ее личность, ее жизнь в науке, ее путь учителя, наставника, воспитателя нескольких поколений не только компаративистов, индологов, но языковедов самых разных специальностей - всех, кому довелось слушать ее лекции, заниматься в ее семинарах, работать под ее руководством. Вера Александровна была замечательным примером научной добросовестности, педагогической ответственности, строгости к себе и доброжелательности к коллегам - стиля жизни, столь характерного для старшего поколения московской университетской среды.

Вера Александровна поступила на романо-германское отделение филологического факультета Московского университета в1942 г. В то время сам филологический факультет, за год до того восстановленный, только формировался в своем составе. Профессура факультета в своей лингвистической части пришла на факультет в основном из Потемкинского московского педагогического института, а в литературоведческой - из ИФЛИ.

Именно в Потемкинском, где до войны работали Александр Александрович Реформатский, Алексей Михайлович Сухотин, Рубен Иванович Аванесов, Петр Саввич Кузнецов и будущий научный руководитель Веры Александровны Михаил Николаевич Петерсон, вопреки напору полуофициальной стихии марризма продолжались и развивались традиции Московской формальной школы Ф.Ф. Фортунатова. Достаточно сказать, что в учебнике А.А. Реформатского «Введение в языкознание», вышедшем первым изданием в 1947 г., но основанном на лекциях, читанных А.М. Сухотиным и П.С. Кузнецовым в Потемкинском, А.А. Реформат- 
ским в литературном институте и М.Н. Петерсоном на филологическом факультете МГУ, можно видеть весьма показательное замечание по поводу необходимости «прежде всего обратиться к целостной и детальной характеристике отдельных языков и их групп и к реальной истории языков» ${ }^{1}$.

Именно этот принцип лег в основу научного мировоззрения Веры Александровны, в 1942 г. слушавшей лекции М.Н. Петерсона и занявшейся под его руководством систематическим изучением санскрита. В 1952 г. Вера Александровна защищает кандидатскую диссертацию «Словосложение в эпическом санскрите», но будучи еще аспиранткой, фактически организует кафедру иностранных языков в тогдашнем физико-техническом факультете МГУ (впоследствии Физтех) и преподает на филологическом факультете. В 1956 г. Вера Александровна активно включается в работу Института восточных языков при МГУ. Институт восточных языков вырос (как и многие другие факультеты МГУ) из филологического факультета - из кафедры, возглавлявшейся А.В. Болдыревым, П.Я. Петровым, Ф.Ф. Фортунатовым. Таким образом, Вера Александровна, организовавшая в 1956 г. на Восточном факультете кафедру индийской филологии и продолжавшая работать на кафедре общего и сравнительно-исторического языкознания, по существу дела, восстанавливала и развивала научно-педагогическую традицию, заложенную в середине XIX в. учителями ее учителей.

Как известно, классическое отечественное востоковедение имеет в основном петербургское происхождение, в Москве же с середины XIX в. востоковедение развивалось главным образом в тесной связи с сравнительно-историческим языкознанием и, пожалуй, в меньшей мере с тюркологией и семитологией, хотя П.Я. Петров настаивал на необходимости развития арабистики. Классическое востоковедение развивалось как комплексная дисциплина, изучавшая культуру как единое целое. Такая комплексная подготовка востоковеда открывала возможность вхождения исследователя в культурный мир изучаемого языка и, соответственно, возможность системного анализа и прогноза современной общественно-политической обстановки в странах так называемого Востока. Поэтому изучение санскрита и древней индийской словесности - предмета фундаментального научного знания - было в то же время тесно связано с общегосударственными задачами и интересами.

Продолжая разработку избранной научной темы, Вера Александровна защищает в 1982 г. докторскую работу «Многофункциональные способы санскритского словообразования», читает в ИСАА и на филологическом факультете все основные курсы кафедры общего и сравнительно-исторического языкознания: «Введение в языкознание», «Общее языкознание», «Историю лингистических учений», «Введение в индийскую филологию»; ведет практические занятия санскритом, но также курс методики преподавания иностранных языков.

Вера Александровна умела мастерски излагать трудные предметы. Ее учебники - не только теории языка «Введение в языкознание для востоковедов» (1970), «Введение в языкознание. Фонетика-фонология. Грамматика» $(1979 ; 1991)$, но и «Начальный курс санскрита» (1956), «Учебник санскрита» (1994) - отличаются поразительной ясностью, систематичностью, цельностью, продуманностью отбора материала. Они в первую очередь воспитывают культуру научного мышления и научного изложения.

${ }_{1}^{1}$ Реформаткий А.А. Введение в языкознание. М.: Гос. изд-во учеб. и пед. лит., 1947. С. 153. 
Помимо прекрасных учебников Веры Александровны, написанных и переизданных ею в различные годы, следует особенно отметить Санскритско-русский словарь, известный в трех изданиях $(1978 ; 1987 ; 1996)$, каждое из которых уточняет и дополняет предыдущие. Это был первый и долгое время единственный санскритско-русский словарь, фундированный многолетним изучением лексики санскрита, результатами сравнительно-исторических исследований, проникновением автора в культуру Индии и языковое мышление, характерное для базового языка - фундамента этой культуры.

Оставаясь постоянным членом кафедры общего и сравнительно-исторического языкознания филологического факультета, Вера Александровна работала на кафедре индийской филологии до 1985 г.

Вера Александровна создала специализацию «Сравнительно-историческое индоевропейское языкознание»; разработала для аспирантов курс по истории науки о языке, разделы которого читались специалистами; организовывала всероссийскую, а затем международные конференции по компаративистике. Так, подготовка компаративистов, подготовка аспирантов кафедры, объединение исследователей в области сравнительно-исторического языкознания и типологии стали единой учебной и научно-исследовательской программой. Вера Александровна приложила немалые усилия для ее реализации.

Академик Б.В. Раушенбах сказал, что ему «по душе то, что еще никогда не делалось» ${ }^{1}$. Действительно, дело не в том, сколько - десять или больше - ученых занимались проблемой, но в ее принципиальной новизне. Так действовали Ф.Ф. Фортунатов, А.А. Шахматов, Н.С. Трубецкой, В.К. Поржезинский, М.Н. Петерсон, Ю.В. Рождественский. Мне кажется, что так думала и Вера Александровна. И этот синтез традиции научной школы и умения найти и решить проблему, обнаруженную и потому интересную, думается, был далеко не чужд и Вере Александровне. Вечная ей память.

${ }^{1}$ Синтез двух систем познания академика Раушенбаха.М.: ВегаПринт, 2015. С. 47. 